\title{
Risk factors that affect reproductive target achievement in fertile dairy cows
}

\author{
S. P. M. Aungier, ${ }^{*}$ J. F. Roche, ${ }^{*}$ M. G. Diskin, $†$ and M. A. Crowe ${ }^{*} \ddagger^{1}$ \\ ${ }^{*}$ School of Veterinary Medicine, University College Dublin, Belfield, Dublin 4, Ireland \\ †Animal and Grassland Research and Innovation Centre, Teagasc, Mellows Campus, Athenry, Co. Galway, Ireland \\ ‡Conway Institute for Biomolecular and Biomedical Research, University College Dublin, Belfield, Dublin 4, Ireland
}

\begin{abstract}
The aims of the present study were to investigate (1) the risk factors that influence the achievement of reproductive targets postpartum (pp) and (2) the key factors that influence pregnancy rate following first artificial insemination (AI) in dairy cows. Ninety-eight Holstein-Friesian pp cows were blood sampled from wk 1 to 4 pp for hematology and biochemistry. Reproductive tract health was assessed weekly by ultrasonography and vaginal mucus scoring. Body condition score (BCS), lameness score, and milk yield were assessed every 2 wk. Milk samples for progesterone assay were collected twice weekly and on d 4, 5, and 7 after AI. Risk factors associated with achieving reproductive targets depended on (1) increased metabolic activity of the liver (increased glutamate dehydrogenase at calving and increased $\gamma$-glutamyl transpeptidase in wk 4), (2) a competent immune system (increased neutrophils in wk 1 ; decreased $\alpha_{1}$-acid glycoprotein in wk 1,2 , and $3)$, (3) an endocrine system that was capable of responding by producing sufficient triiodothyronine in wk 2 and increased insulin-like growth factor I in wk 3 and 4, (4) a lower negative energy balance status (decreased nonesterified fatty acid concentration in wk 1 ; decreased $\beta$-hydroxybutyrate concentration in wk 2 ; BCS loss between calving and d $28 \mathrm{pp}<0.5$ ), (5) good reproductive tract health [normal uterine scan at d 45 pp; clear vaginal mucus discharge at first ovulation and at d $45 \mathrm{pp}$; resumed ovarian cyclicity by the end of the voluntary waiting period ( $\geq \mathrm{d} 35 \mathrm{pp}$ )], and (6) adequate diet (to ensure increased glutathione peroxidase in $\mathrm{wk}$ 2 and 3 and increased magnesium in wk 4). Risk factors that increased the odds of a successful first AI were previous ovulation(s) (odds ratio $=3.17$ per ovulation), BCS $>2.5$ at AI (odds ratio $=3.01$ ), and clear vaginal mucus (score $=0$ ) compared with purulent mucus (score $>0) 4 \mathrm{~d}$ after first AI (odds ratio $=2.99$ ). In conclusion, this study identified key risk factors in the early pp period that give a higher probability of cows
\end{abstract}

Received August 22, 2013.

Accepted February 12, 2014.

${ }^{1}$ Corresponding author: mark.crowe@ucd.ie achieving their reproductive targets and of having a first-AI pregnancy.

Key words: fertility, insulin-like growth factor I, negative energy balance, thyroid function

\section{INTRODUCTION}

The reproductive efficiency of high-yielding dairy cows is influenced by their postpartum (pp) intervals to uterine involution, first ovulation, first AI, and conception. Thatcher et al. (2006) suggested that complete physical involution should occur in a short period of time pp before first ovulation. It has been suggested that early resumption $(<21 \mathrm{~d})$ of ovulation pp was associated with improved reproductive performance in those cows that continue to have normal estrous cycles (Opsomer et al., 2000; Galvão et al., 2010). However, dairy cows enter a period of negative energy balance (NEB), which induces decreased circulating IGF-I concentration during the time pp when the uterus must undergo extensive repair after calving. Wathes et al. (2011) found that cows with a severe NEB had alterations to the IGF- and insulin-signaling pathways in the pp endometrium. This may affect the rate of tissue repair, with a possible negative effect on subsequent fertility. One of the key physiological roles of $\mathrm{PGF}_{2 \alpha}$ in the first month pp is to induce uterine contractility and so promote uterine involution (LeBlanc, 2008). Circulating $\mathrm{PGF}_{2 \alpha}$ is converted rapidly to $\mathrm{PGF}_{2 \alpha}$ metabolite (PGFM) in the lungs. In normal cows, the longer the time that concentrations of PGFM remained elevated pp, the shorter the time to gross uterine involution (Lindell et al., 1982; Madej et al., 1984) and resumption of normal estrous cycles (Madej et al., 1984). In cows with purulent uterine discharge, PGFM concentrations were higher and remained elevated for longer than in normal cows, yet involution was delayed (Lindell et al., 1982; Del Vecchio et al., 1994). The inflamed uterus may provoke an increased magnitude and duration of $\mathrm{PGF}_{2 \alpha}$ release from the uterus (Lindell et al., 1982) and it may become refractory to this continuous release of $\mathrm{PGF}_{2 \alpha}$ (Rodriguez-Martinez et al., 1987). In healthy cows, the previously gravid uterine horn should achieve a diameter of 3 to $4 \mathrm{~cm}$ by 25 to $30 \mathrm{~d}$ pp and a cervical 
diameter $<5 \mathrm{~cm}$ by $40 \mathrm{~d}$ pp (Gier and Marion, 1968). However, involution of the uterus and cervix is not complete until approximately 40 to $50 \mathrm{~d}$ pp (Gier and Marion, 1968; Sheldon, 2004; Scully et al., 2013). Uterine involution can also be affected by age, breed, nutrition, and other factors, so delayed uterine involution is not a specific indicator of uterine disease (Fonseca et al., 1983).

A study by Dubuc et al. (2012) identified risk factors associated with early ovulation $(<21 \mathrm{~d} \mathrm{pp})$, which included season, parity, decreased haptoglobinemia, and decreased serum NEFA concentration before and after parturition. Risk factors for prolonged anovulation (anovulatory $>63 \mathrm{~d} \mathrm{pp}$ ) included cytological endometritis, increased haptoglobinemia, and greater serum NEFA concentrations before and after parturition. Negative energy balance inhibits LH pulse frequency, and low concentrations of blood glucose, insulin, and IGF-I result in reduced estradiol- $17 \beta$ production by the dominant follicles (Butler, 2000). Negative energy balance not only reduces insulin and IGF-I concentrations (Beam and Butler, 1999; Butler, 2000) but also increases growth hormone (GH) concentrations (Vicini et al., 1991), leading to delays in resumption of estrous cycles, impaired oocyte quality and corpus luteum (CL) function. The development of extended luteal phases after first ovulation pp has been reported to be higher in cows with pp endometritis and pyometra (Mateus et al., 2002). The extended luteal phase probably occurs because the infection switches the endometrial epithelial secretion of prostaglandins from the $\mathrm{F}$ to the $\mathrm{E}$ series by a phospholipase A2-mediated mechanism that disrupts luteolysis (Sheldon et al., 2008; Herath et al., 2009).

A decline in pregnancy rate to first AI has been associated with abnormal reproductive, metabolic, and endocrine factors (Diskin, 2008). Conception rates were found to be approximately $20 \%$ lower for cows with endometritis, with the calving to conception interval being $31 \mathrm{~d}$ longer (Borsberry and Dobson, 1989). Despite the multifactorial nature of bovine subfertility, the current literature is lacking in research where a multifactorial approach has been used to identify the key risk factors associated with cows that can achieve reproductive targets and become pregnant in a timely fashion. Therefore, the aims of the present paper were to determine (1) the risk factors that influence the achievement of reproductive targets pp and (2) the key factors that influence pregnancy rate at $30 \mathrm{~d}$ after first AI in dairy cows. To address these aims, the following hypotheses were tested: (1) specific metabolic, endocrine, mineral, reproductive tract health, liver function, immune status, BCS, and lameness score factors monitored in the early pp period are related to fertile cows achieving their reproductive targets (interval to ovulation, involution, first AI, and conception); and (2) at the time of the first AI, reproductive tract health, milk production, BCS and lameness score variables are related to the probability of a pregnancy following this $\mathrm{AI}$ in fertile cows.

\section{MATERIALS AND METHODS}

\section{Study Animals}

The study was conducted between January and August 2009 on a commercial all-year-round milkproducing dairy farm in County Kildare, Ireland. A total of 98 cows from the spring-calving cohort were selected on the basis of having had single-calf births and calving after January 19. The cows were divided into 3 groups representing first lactation $(\mathrm{n}=31)$, second lactation $(\mathrm{n}=27)$, and a third lactation group made up of lactations 3 to $8(\mathrm{n}=40)$. The calving period was from January 19 to May 5, with a calving distribution of $26,22,35,14$, and 1 cow in the months January to May, respectively. From the day of drying-off up to $21 \mathrm{~d}$ before calving, dry cows and in-calf heifers were fed a far-off diet consisting of grass silage, straw, and a vitamin and mineral mix. The close-up diet, from $21 \mathrm{~d}$ before calving to expected day of calving, aimed to exceed the energy requirements. The diet supplied, on average, $117 \mathrm{MJ} /$ animal per day, as the parities were not separated. The diet consisted of grass silage, straw, soybean meal, Dairy Blend (1 kg of $20 \%$ CP; Charles R. Wynne Foods Ltd., Kildare, Ireland), and vitamin and mineral mix $[150 \mathrm{~g} / \mathrm{cow}$ per day of the mix: vitamin A $(600,000 \mathrm{IU} / \mathrm{kg})$, vitamin $\mathrm{D}_{3}(200,000$ $\mathrm{IU} / \mathrm{kg})$, vitamin $\mathrm{E}(10,000 \mathrm{IU} / \mathrm{kg})$, cobalt $(100 \mathrm{mg} / \mathrm{kg})$, iodine $(500 \mathrm{mg} / \mathrm{kg})$, selenium $(42 \mathrm{mg} / \mathrm{kg})$, manganese $(3,800 \mathrm{mg} / \mathrm{kg})$, copper $(3,000 \mathrm{mg} / \mathrm{kg})$, zinc $(8,000 \mathrm{mg} /$ $\mathrm{kg}$ ), phosphorus (6\%), and magnesium (26.5\%)].From calving, cows were fed grass silage, straw, maize silage, proprietary coarse blend ( $8 \mathrm{~kg}$ of $20 \% \mathrm{CP}$ ) and brewers grain. This was topped off with $1 \mathrm{~kg}$ of a proprietary compounded concentrate $(15 \% \mathrm{CP})$ in the parlor at both a.m. and p.m. milking. From late March, cows that had calved were let out to graze grass by day and the level of grass and maize silage was reduced accordingly. From mid April, cows were outdoors full time, but were fed a TMR buffer diet, with reduced grass and maize silage consumption, after each milking, and were fed the proprietary compounded concentrate during each milking. The cows in the study group had a mean \pm standard error of the mean 305-d milk yield of 8,800 $\pm 154 \mathrm{~kg}$ with a mean peak yield of $43.9 \mathrm{~kg} / \mathrm{d}$ for 2009 to 2010. The automatic heat activity monitor Heatime (SCR Engineers Ltd., Netanya, Israel).was used to de- 
Table 1. Definition of terms used to define a normal and abnormal uterine ultrasound scan, and vaginal mucus character score

Test
of ultrasound reproductive tract scores $^{1}$

\section{Score}

Grade 1: uterine infection absent, involuted, cyclic

Grade 2: mild clinical endometritis, cyclic $^{2}$

Grade 3: severe clinical endometritis, cyclic

Grade 4: mild/severe clinical endometritis, anovulatory

Grade 5: pyometra, corpus luteum

Grade 6: uterine infection absent, involuted, anestrus

B) This study defined both a normal and abnormal uterine ultrasound scan based on the ultrasound scan

Normal uterine ultrasound scan: grades 1 and 6

Abnormal uterine ultrasound scan: grades $2^{2}, 3,4,5$

grades assigned in the test above

C) Vaginal mucus character score ${ }^{3}$

Score 0: Clear translucent vaginal mucus

Score 1: Clear translucent vaginal mucus interspersed with discrete flecks

of purulent exudate present (not quantified by Williams et al., 2005)

Score 2: $\leq 50 \%$ white or off-white mucopurulent material

Score 3: $\geq 50 \%$ white, yellow or sanguineous purulent material

D) This study defined both a vaginal mucus character score $=$ 0 and $>0$ based on the character scores assigned

Vaginal mucus character score $=0$ : Williams score $=0$

in the test directly above ${ }^{4}$

Vaginal mucus character score $>0$ : Williams score $=1,2$, or 3

${ }^{1}$ Uterine health status as defined by Mee et al. (2009).

${ }^{2} \mathrm{~A}$ grade 2, up to wk 3 inclusive, is generally considered normal mixed echogenicity fluid within the uterine lumen associated with involution.

${ }^{3}$ Vaginal mucus character score as defined by Williams et al. (2005).

${ }^{4}$ Vaginal mucus character scores of 1,2 , and 3 were grouped together and assigned a score of $>0$.

tect cows in estrus. Cows were then mated using AI. This was carried out by a farm-based AI technician using the a.m./p.m. rule (Trimberger and Davis, 1943; Trimberger, 1948). The study was approved by the animal research ethics committee of University College Dublin (Belfield, Dublin, Ireland) and was licensed in accordance with the Cruelty to Animals Act (Ireland 1876) and the European Union Directive 86/609/EC.

\section{Monitoring of Health and Physiological Status Postpartum}

Before the initiation of the study, serum samples were collected to confirm that (1) bovine viral diarrhea, (2) infectious bovine rhinotracheitis, (3) Salmonella Dublin and Salmonella Typhimurium, and (4) Leptospira borgpetersenii serovar Hardjo were absent within the herd. At calving, the incidence of dystocia, calving-related injuries, retained placenta, and milk fever was recorded. Reproductive tract status was monitored weekly by ultrasonography determination of the uterus and ovaries and vaginal mucus character score from d 10 to $60 \mathrm{pp}$ for cows that had resumed normal ovarian activity with both a normal uterine ultrasound scan (as defined by Mee et al., 2009; Table 1A and B) and a clear vaginal mucus character score (as defined by Williams et al., 2005; Table 1C). For cows that continued to show evidence of an abnormal uterine scan at d 60, diagnostic ultrasonography continued until they had both a normal uterine scan and the vaginal mucus discharge had a character score of 0 on 2 consecutive weekly visits. The ultrasound scanner used was a BCF Easi-Scan digital scanner (BCF Technology Ltd., Livingston, UK) set on "detail" for reproductive tract scanning. A $5-\mathrm{MHz}$ linear rectal probe (BCF Technology Ltd.) operating at a depth of $3.5 \mathrm{~cm}$ was used. Body condition (Edmonson et al., 1989) and lameness scoring (Sprecher et al., 1997) were carried out every 2 wk from calving. Milk yield was recorded twice monthly up to 100 DIM. Pregnancy status was confirmed by uterine ultrasonography $30 \mathrm{~d}$ after AI.

\section{Milk Sampling and Progesterone Analysis}

Whole-milk samples were collected twice weekly on Tuesday and Friday morning milkings in $30-\mathrm{mL}$ plastic sample bottles, preserved with 3 Lactabs Mark III tablets (30 mg of potassium dichromate; Thompson and Capper Ltd., Runcorn, UK)and frozen at $-20^{\circ} \mathrm{C}$ until subsequently analyzed. Milk collection continued until an animal was diagnosed pregnant by uterine ultrasonography. Additional milk samples were collected on d 4, 5, and 7 after AI. Samples were analyzed for milk progesterone $\left(\mathbf{P}_{4}\right)$ concentrations using a validated solid-phase RIA (Coat-A-Count Progesterone; Siemens Medical Solutions Diagnostics, Los Angeles, CA) as previously described (Forde et al., 2011). Limits of detection, precision, and quality control data for the hormone immunoassays are presented in Table 2. Progesterone concentrations were used to generate profiles to determine the interval to resumption of ovulation pp and the length of the interovulatory periods as previously defined by Royal et al. (2000). Ovulation was deemed to have occurred if at least 2 consecutive 
Table 2. Limits of detection, precision, and quality control data for the hormone immunoassays used in the study

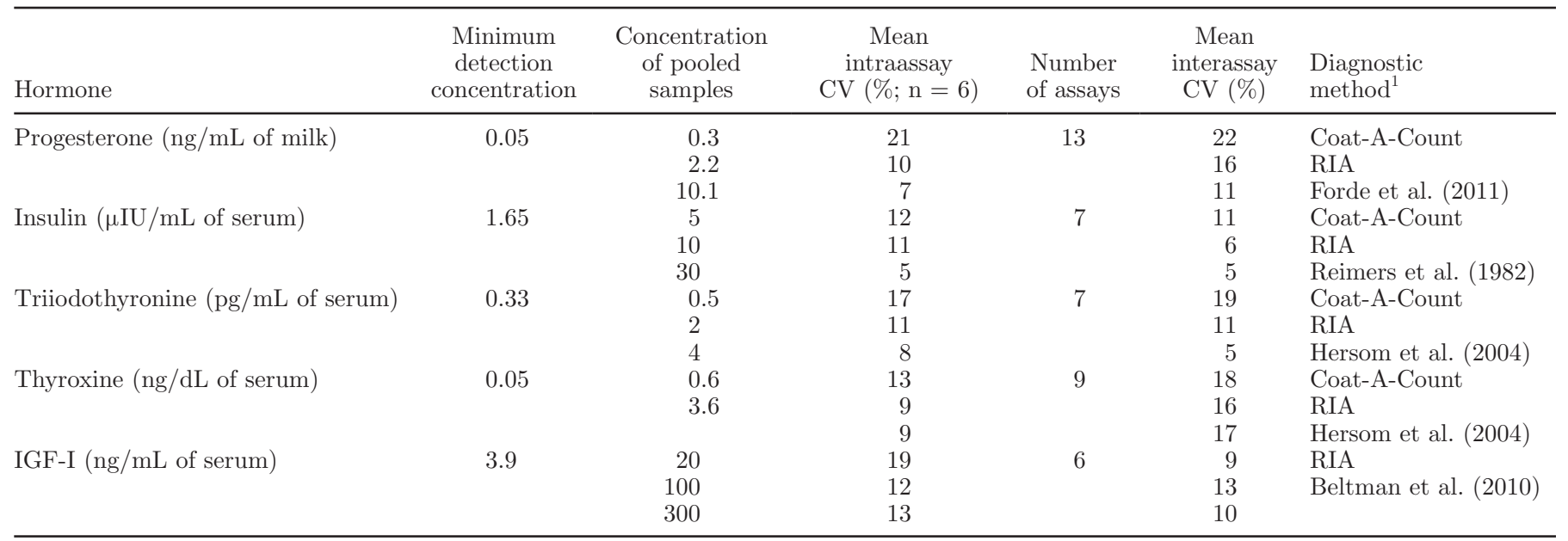

${ }^{1}$ Coat-A-Count (Siemens Medical Solutions Diagnostics, Los Angeles, CA).

milk samples had a $\mathrm{P}_{4}$ concentration $\geq 0.6 \mathrm{ng} / \mathrm{mL}$. The total number of expected ovulatory periods could then be identified for each cow from an analysis of their $\mathrm{P}_{4}$ profiles.

\section{Collection of Blood Samples for Routine Biochemistry, Hematology, and Hormone Analysis}

Blood samples were collected from cows at calving and subsequently at weekly intervals up to wk $4 \mathrm{pp}$. Blood samples for hematology were analyzed on the day of collection. For the remainder of the assays, blood samples were stored at $4^{\circ} \mathrm{C}$ for $24 \mathrm{~h}$ and then centrifuged at $2,000 \times g$ for $20 \mathrm{~min}$ at $4^{\circ} \mathrm{C}$. The serum supernatant was collected and stored at $-20^{\circ} \mathrm{C}$ until assayed. Samples were analyzed for routine biochemistry [NEFA; BHBA; Mg; Cu; erythrocyte glutathione peroxidase (GPX), used as a retrospective monitor of circulating selenium concentration; $\alpha_{1}$-acid glycoprotein (AGP); $\gamma$-glutamyl transpeptidase (GGT); glutamate dehydrogenase (GLDH)] and also for insulin, free 3,3',5-triiodothyroinine $\left(\mathbf{T}_{3}\right)$ and free thyroxine $\left(\mathbf{T}_{4}\right)$, using validated solid-phase RIA (Coat-A-Count kit for each respective hormone; Siemens Medical Solutions Diagnostics) as described previously (Reimers et al., 1982; Hersom et al., 2004). Serum concentrations of IGF-I were determined using an RIA, which followed ethanol-acetone-acetic acid extraction (at a ratio of 60:30:10, as described previously by Beltman et al., 2010). Limits of detection, precision, and quality control data for the hormone immunoassays are presented in Table 2.

On a practical note, blood samples were always collected immediately after the cows were milked in the morning, as this was the time when direct access to the cows was possible. However, concentrate feeding during milking affects the blood insulin concentrations of cows.

\section{Definitions}

The cow breeding season was the planned breeding season that extended from March 31 to August 1. Cows became eligible for breeding during that period once they were $35 \mathrm{~d}$ or more calved. The intervals to reproductive targets were determined from the time the cow was eligible for breeding, so that cows that calved more than $35 \mathrm{~d}$ in advance of the start date of the breeding season would not be unfairly biased against.

The duration of the pp anestrous interval was the interval to first ovulation based on milk progesterone analysis.

\section{Statistical Analysis}

All analyses were performed with SAS (version 9.1, 2002-2003; SAS Institute Inc., Cary, NC). The intervals to reproductive targets were determined from the start of the cow breeding season and not from the time a cow calved. This was because if cows had calved earlier in the year before the breeding season started, they would have an artificially prolonged interval to reach reproductive targets. Censored cows were defined as cows that only had data up to a certain time point available and so were excluded from further analysis after that time point. These cows would have received either a treatment before $\mathrm{AI}$ or reached the end of the breeding season (August 1) without being inseminated or without having a $30-\mathrm{d}$ pregnancy. The following treatment protocols were available for such cows: (1) $\mathrm{PGF}_{2 \alpha}$ (cloprostenol) treatment was given to shorten the estrous cycle 
in cows, within the last $3 \mathrm{wk}$ of the breeding season, if a CL was present; (2) clinical endometritis was treated with the intrauterine antibiotic cephapirin (Metricure 500-mg suspension in a 19-g injector for intrauterine use; MSD Animal Health, Milton Keynes, UK), and a cloprostenol treatment was also given if a CL was present; and (3) cows with pyometra were treated with cloprostenol and intrauterine cephapirin. A pyometra was confirmed when ultrasonography identified a large volume $>1 \mathrm{~cm}$ (estimated using the scale bar on the ultrasound console) of mixed echogenicity (gray) fluid with hyperechoic particles in a circular uterine lumen without infolding of the endometrium and with variable uterine wall thickness in the presence of a CL (Mee et al., 2009). One hundred and twenty-three inseminations were carried out where the cows did not receive a treatment beforehand. Sixty-seven inseminations were carried out where cows did receive a treatment beforehand. The duration of the pp anestrous interval was defined as (1) short anestrus: $\leq 25 \mathrm{~d}$ after calving, (2) mild anestrus: 26 to $44 \mathrm{~d}$ after calving, and (3) prolonged anestrus: $\geq 45 \mathrm{~d}$ after calving. The presence or absence of uterine infection was defined as either a normal or abnormal uterine ultrasound scan (as defined by Mee et al., 2009; Table 1A and B). Uterine infection on ultrasonography was identified as a fluid of mixed echogenicity (gray or white). A clear translucent vaginal mucus sample with a character score of 0 was defined as normal. A vaginal mucus sample with purulent exudate present (as defined by Williams et al., 2005; Table 1C and D) was defined as abnormal and said to have a character score $>0$. Data on the relationships between endocrine profiles, metabolic, and health variables with (1) interval to first ovulation, (2) interval to uterine involution, (3) interval to first AI, and (4) interval to conception leading to a first 30-d pregnancy were analyzed in separate weekly models between calving and wk 4 pp with survival analysis, using Cox's proportional hazards regression (PROC PHREG in SAS; Collett, 1994). Models were built by manual backward stepwise elimination. At each step, the 1 variable with the highest $P$-value was removed and the model rerun again until all remaining variables were significant at $P<0.1$. These variables were then rerun in a final model until only variables with $P<0.05$ remained. The variables BCS loss $\geq 0.5$ or $<0.5$ units between calving and d 28 pp, 100-d 3.5\% FCM yield, lactation group, vaginal mucus discharge clear (character score $=0$ ) or not (character score $>0$ ) on 2 consecutive weekly visits by d $45 \mathrm{pp}$, and uterine infection absent (normal uterine ultrasound scan) or not (abnormal ultrasound scan) on 2 consecutive weekly visits by d 45 pp were analyzed together in a separate model (PROC TPHREG in SAS). Analysis of the model interval to first AI had
SCC $\left(<200 \times 10^{3}\right.$ or $\geq 200 \times 10^{3}$ cells $/ \mathrm{mL}$; Schepers et al., 1997), BCS $(\leq 2.5,2.75$, or $\geq 3)$ and lameness score $(1$ or $\geq 2)$ taken at the start of the cow's own breeding season and also the variable whether the cow had or had not resumed estrous cycles, either before or at that time. The other 4 variables were also included and PROC TPHREG was rerun until only those with a $P<0.05$ remained. Kaplan-Meier survival curves were drawn (PROC LIFETEST in SAS). Logistic regression models were used to examine (1) the probability of a prolonged luteal phase at the time of the first pp ovulation and (2) the probability of the first AI resulting in a 30-d pregnancy. In (1), a separate model was used for each week from calving to wk 4 pp to analyze the endocrine profiles, metabolic, and health variables in each week and then the significant variables $(P<0.1)$ from each week were rerun in a final model and those with $P<0.05$ were retained. A further model was run using SCC $\left(<200 \times 10^{3}\right.$ or $\left.\geq 200 \times 10^{3}\right)$, lactation group, duration of anestrus, and the record of $\operatorname{BCS}(\leq 2.5$, 2.75 , or $\geq 3$ ), lameness score ( 1 or $\geq 2)$, vaginal mucus character score (score $=0$ or $>0$ ), and uterine infection status (normal or abnormal uterine ultrasound scan) at the time of the first ovulation. In (2), the variables at the time of the first AI that were used were vaginal mucus character score $4 \mathrm{~d}$ after AI, normal ultrasound scan at AI, 3.5\% FCM yield, number of previous ovulations, BCS (thin $\leq 2.5$ vs. healthy: 2.75 or 3 ), lameness score $(1$ or $\geq 2)$, and SCC $\left(<200 \times 10^{3}\right.$ or $\geq 200 \times 10^{3}$ cells $/ \mathrm{mL}$ ). A receiver operating characteristic (ROC) curve was used to assess the sensitivity and specificity of the logistic regression models. The ROC curve is a graphic plot of the sensitivity versus 1 - specificity. Sensitivity is the ability of the model to predict the occurrence of the model outcome. It is the percentage of true positives identified out of the total number of true positives. Specificity is the ability of the model to avoid false positives (making a prediction of an occurrence when it is not true: 1 - specificity). The closer the area under the curve is to 1 , the better the prediction.

\section{RESULTS}

\section{Different Approaches to Assessment of Herd Reproductive Targets}

Of the 98 cows in the study, 56 never received a treatment. Fifty of these cows were diagnosed pregnant at $30 \mathrm{~d}$ after $\mathrm{AI}$ (from $80 \mathrm{AI}$ ) and the remaining 6 cows never achieved a 30-d pregnancy (from 13 AI) during their breeding season. All untreated cows, with a voluntary waiting period of at least $43 \mathrm{~d}$ and the full $123-\mathrm{d}$ breeding season conceived. Cows received a treatment, either to shorten their estrous cycle $(\mathrm{n}=21$ cows $)$ if 
they were close to the end of the breeding season or to treat the outcome of an abnormal uterine condition as determined by ultrasound scan $(\mathrm{n}=21$ cows $)$. Even among these 42 cows, a longer voluntary waiting period and a longer breeding season improved the likelihood of a 30-d pregnancy.

\section{Postpartum Interval to Uterine Involution}

In the present study, the mean \pm standard error of the mean time to involution pp was $39 \pm 3 \mathrm{~d}$ (median $=31 \mathrm{~d} ; \mathrm{n}=91 \mathrm{cows}$ ). The involution date was unknown for the remaining 7 cows. Seventy-two cows were included in the survival analysis of the pp interval to involution; 66 involuted and 6 had an unknown involution date. The key risk factors associated with cows having involuted by a given time pp were the ability to cope with higher liver metabolic rates (GLDH concentration at calving), the immune response (neutrophil concentration in wk 1, AGP and GPX concentrations in wk $2 \mathrm{pp}$, and the presence of uterine infection on ultrasonography at d-45 pp), the severity of NEB (elevated NEFA concentration in wk-1 pp and BCS loss during the first $28 \mathrm{~d} \mathrm{pp}$ ) and the peripheral circulating concentrations of IGF-1 in wk-3 pp. Data on these risk factors are presented in Table 3.

\section{Postpartum Interval to First Ovulation}

In the present study, based on twice-weekly milk $\mathrm{P}_{4}$ measurements and weekly ovarian ultrasonography, the mean \pm standard error of the mean interval to resumption of ovulation pp was $45 \pm 3 \mathrm{~d}$ (median $=35 \mathrm{~d}$; range 11 to $142 \mathrm{~d} ; \mathrm{n}=98$ cows). The results $(\mathrm{n}=91$ cows; 79 cows ovulated and a further 12 cows were censored at some point from further analysis due to missing data) indicate that increased concentrations of $\mathrm{T}_{3}$ in wk $2 \mathrm{pp}$, and IGF-I and $\mathrm{Mg}$ in wk 4 pp increased the probability of resumption of ovulation at any given time point pp (Table 4). A separate analysis indicated that a loss in BCS of $<0.5$ units compared with a loss of $\geq 0.5$ units ( $\mathrm{n}=98$ cows; of which 73 cows had a loss of $<0.5$ units) between calving and d-28 pp increased the probability of resuming ovulation by any given time $\mathrm{pp}$ by $62 \%$ (hazard ratio $=1.62 ; P=0.06)$.

\section{Prolonged Luteal Phase After the First Ovulation Postpartum}

Based on twice-weekly milk $\mathrm{P}_{4}$ measurements and weekly ovarian ultrasonography, 20 of 98 cows (20.4\%) cows developed a prolonged luteal phase in this study ( $\geq 19$ d). Eight $(24.4 \%)$ of these cows were from the short anestrous group, which had their first pp ovulation within $25 \mathrm{~d}$ of calving ( $\mathrm{n}=28$ cows); a further $10(28.6 \%)$ cows were from the mild anestrous group, which ovulated between d 26 and $44 \mathrm{pp}(\mathrm{n}=41$ cows); and $2(6.9 \%)$ cows were from the prolonged anestrous group, which ovulated $\geq 45 \mathrm{~d} p p(\mathrm{n}=29$ cows $)$. Cows in the short anestrous group where equally as likely to develop a prolonged luteal phase as those in the mild anestrous group $(P=0.25)$.

Results from a model based on an analysis of 84 cows (data missing for 14 cows) indicated that if cows had a clear vaginal mucus discharge by the time of first ovulation, their odds of a normal luteal phase increased (odds ratio $=5.4 ; 95 \% \mathrm{CI}=1.15$ to 25.34 ; $P=0.03$; area under the ROC curve $=0.64$ ). The factors lactation group $(P=0.99)$, lameness at ovulation $(P=0.82)$, duration of the pp anestrous interval $(P$ $=0.6)$, a normal ultrasound scan at ovulation $(P=$ $0.55)$, and BCS at ovulation $(P=0.12)$ had no effect on the occurrence of a prolonged luteal phase. Using a different model $(\mathrm{n}=78$ cows, with 17 cows having a prolonged luteal phase), the key factors identified were (1) a higher circulating concentration of BHBA in wk-2

Table 3. Final proportional regression hazards model of time to involution postcalving ( $\mathrm{n}=72$ cows)

\begin{tabular}{lccc}
\hline Variable $^{1}$ & $\begin{array}{c}\text { Parameter } \\
\text { estimate }+\mathrm{SE}\end{array}$ & $\begin{array}{c}\text { Hazard } \\
\text { ratio }\end{array}$ & $P$-value \\
\hline Glutamate dehydrogenase at calving $(\mathrm{U} / \mathrm{L})$ & $0.04+0.01$ & 1.04 & 0.005 \\
Insulin at wk-1 pp $(\mu \mathrm{IU} / \mathrm{mL})$ & $-0.42+0.18$ & 0.65 & 0.02 \\
Neutrophils at wk-1 pp $\left(10^{9} / \mathrm{L}\right)$ & $0.3+0.09$ & 1.35 & 0.001 \\
NEFA at wk-1 pp $(\mathrm{mmol} / \mathrm{L})$ & $-1.06+0.49$ & 0.35 & 0.03 \\
Insulin at wk-2 pp $(\mu \mathrm{IU} / \mathrm{mL})$ & $-0.34+0.14$ & 0.71 & 0.02 \\
$\mathrm{\alpha}_{1}$-Acid glycoprotein at wk-2 pp $(\mathrm{mg} / \mathrm{mL})$ & $-0.21+0.07$ & 0.81 & 0.004 \\
Glutathione peroxidase at wk-2 pp $(\mathrm{U} / \mathrm{mg}$ of $\mathrm{Hb})$ & $0.33+0.15$ & 1.01 & 0.05 \\
IGF-I at wk-3 pp $(\mathrm{ng} / \mathrm{mL})$ & $0.91+0.33$ & 2.49 & 0.03 \\
BCS loss from calving to d-28 pp of $<0.5 \mathrm{U}$ & $-1.0+0.36$ & 0.37 & 0.006 \\
Abnormal uterine scan at d-45 pp & & & \\
${ }^{1}$ pp $=$ postpartum; $\mathrm{Hb}=$ hemoglobin. & & & \\
${ }^{2}$ The hazard ratio for a $50 \mathrm{ng} / \mathrm{mL}$ increase is shown in this table due to the large magnitude of changes in IGF-I \\
concentrations during the pp period.
\end{tabular}


Table 4. Final proportional regression hazards model of time to ovulation postcalving $(\mathrm{n}=91$ cows)

\begin{tabular}{lccc}
\hline Variable & $\begin{array}{c}\text { Parameter } \\
\text { estimate }+\mathrm{SE}\end{array}$ & $\begin{array}{c}\text { Hazard } \\
\text { ratio }\end{array}$ & $P$-value \\
\hline Triiodothyronine at $\mathrm{wk}^{2}-\mathrm{pp}^{1}(\mathrm{pg} / \mathrm{mL})$ & $0.61+0.26$ & 1.84 & 0.02 \\
IGF-1 at wk-4 pp $(\mathrm{ng} / \mathrm{mL})$ & $0.15+0.09$ & 1.17 & 0.08 \\
Magnesium at wk-4 pp $(\mathrm{mmol} / \mathrm{L})$ & $0.46+0.14$ & 1.58 & 0.002 \\
${ }^{1} \mathrm{pp}=$ postpartum. & & \\
${ }^{2}$ The hazard ratio for a $50 \mathrm{ng} / \mathrm{mL}$ increase is shown in this table due to the large magnitude of changes in IGF-I \\
concentrations during the $\mathrm{pp}$ period. \\
${ }^{3}$ The hazard ratio for a $0.1 \mathrm{mmol} / \mathrm{L}$ increase is shown in this table because a 1 mmol/L increase in magnesium \\
concentration would be a very large amount.
\end{tabular}

pp (odds ratio $=0.28 ; 95 \% \mathrm{CI}=0.11$ to $0.75 ; P=$ 0.01 ) decreased the odds of a normal luteal phase by $72 \%$ and (2) a higher concentration of GGT in wk-4 pp (odds ratio $=1.46 ; 95 \% \mathrm{CI}=1.15$ to $1.85 ; P=0.002$ ) increased the odds of a normal luteal phase by a factor of $46 \%$. The c statistic for the area under the ROC curve for this model was 0.77 . The mean \pm standard error of the mean of GGT in wk-4 pp in cows that did not have a prolonged luteal period was $12.5 \pm 0.7$ $\mathrm{U} / \mathrm{L}$ (range: 6 to $41 \mathrm{U} / \mathrm{L}$ ) and $8.9 \pm 0.7 \mathrm{U} / \mathrm{L}$ (range: 4 to $14 \mathrm{U} / \mathrm{L}$ ) in those that did. Furthermore, as AGP concentrations increased in wk 1 , the probability of a normal luteal phase decreased (odds ratio $=0.76 ; P=$ $0.06)$. The factors lactation group $(P=0.99)$, lameness at ovulation $(P=0.75)$, duration of the pp anestrous interval $(P=0.6)$, a normal ultrasound scan at ovulation $(P=0.5)$, SCC at ovulation $(0.16)$, and BCS at ovulation $(P=0.12)$ had no effect on the occurrence of a prolonged luteal phase.

\section{Interval to First AI}

Cows were censored from further analysis once they received either a treatment before AI or had reached the end of the farmer's breeding season without being inseminated. Ninety-seven cows (67 received a first $\mathrm{AI}$ and 30 were censored) were included in an analysis of blood variables, which identified that cows with a higher IGF-I concentration and a lower AGP concentration in wk 3 had a greater probability of having been inseminated by any given time after the start of their own breeding season (Table 5). Another analysis that included 91 cows (62 received a first AI and 29 were censored) identified 2 factors that decreased the probability of a cow having been inseminated by a certain time: (1) a vaginal mucus score $>0$ at d $45 \mathrm{pp}$ and (2) if a cow had not resumed ovarian cyclicity by the start of her breeding season (Table 5). The presence of an abnormal uterine ultrasound scan at d-45 pp approached significance (hazard ratio $=0.59 ; P=0.06$ ), with the effect that the probability of being inseminated by any time point was lower by $41 \%$ compared with a cow that had a normal uterine ultrasound scan. If ovulation had not resumed by the start of the cow breeding season, the estimated mean \pm standard error of the mean interval to AI was $56 \pm 4 \mathrm{~d}$ (estimated median $=58 \mathrm{~d}$; $\mathrm{n}$ $=11$ cows inseminated and 15 censored), and if it had resumed, the estimated mean \pm standard error of the mean interval to AI was $31 \pm 4 \mathrm{~d}$ (estimated median $=21 \mathrm{~d} ; \mathrm{n}=51$ cows inseminated and 14 censored; Figure 1A). In cows that had a vaginal mucus discharge character score $>0$ at d-45 pp, the estimated mean \pm standard error of the mean interval to AI was $43 \pm 4 \mathrm{~d}$ (estimated median $=42 \mathrm{~d} ; 28$ cows inseminated and 19 censored). With a clear vaginal mucus discharge score $=0$, the estimated mean \pm standard error of the mean interval to AI was $36 \pm 5 \mathrm{~d}$ (estimated median $=22 \mathrm{~d}$; 34 cows were inseminated and 10 were censored; Figure 1B). The following variables did not have an effect on the outcome: the SCC at the start of the cow breeding season $(P=0.89)$, BCS at the start of the cow's breeding season $(P=0.69), 100-\mathrm{d} 3.5 \% \mathrm{FCM}$ yield $(P$ $=0.54)$, lame at the start of the cow's breeding season $(P=0.27)$, and lactation group $(P=0.12)$.

\section{Interval to Conception Leading to a First 30-d Pregnancy Diagnosed by Ultrasonography}

Of the 98 cows in the study, 50 were scanned pregnant at $30 \mathrm{~d}$ after AI without a previous treatment. The remaining 48 cows were censored due to receiving a treatment or reaching the end of their breeding season. The estimated mean \pm standard error of the mean time from the start of a cow breeding season to conception, leading to a positive 30-d pregnancy test, was $69 \pm 5$ d (estimated median time $=65 \mathrm{~d} ; 95 \% \mathrm{CI}=47$ to 94 d). Analysis $(\mathrm{n}=81 \mathrm{cows})$ showed that 40 cows had a conception leading to a 30 -d pregnancy, 41 were censored (due to either a treatment before the conception, or the end of the breeding season occurred), and 17 cows were missing values for predictors. An increase in IGF-I and GPX concentration in wk-3 pp and a shorter 
Table 5. Proportional regression hazards model of interval to first AI postcalving after the individual voluntary waiting period for each cow postpartum (pp) has ended

\begin{tabular}{lccc}
\hline Variable $^{1}$ & $\begin{array}{c}\text { Parameter } \\
\text { estimate }+ \text { SE }\end{array}$ & $\begin{array}{c}\text { Hazard } \\
\text { ratio }\end{array}$ & $P$-value \\
\hline $\mathrm{AGP}^{2}$ at wk-3 pp $(\mathrm{mg} / \mathrm{mL})$ & $-0.11+0.05$ & 0.89 \\
IGF-I at wk $3 \mathrm{pp}^{3}(\mathrm{ng} / \mathrm{mL})$ & $0.3+0.1$ & 0.03 \\
$\mathrm{~A}$ cow has not resumed ovarian cyclicity by the start of her breeding season & $-1.24+0.34$ & 1.35 & 0.004 \\
Vaginal mucus discharge character score $>0$ at d-45 pp & $-0.62+0.26$ & 0.29 & 0.0002 \\
\hline
\end{tabular}

${ }^{1}$ The first 2 variables are endocrine and immune variables, with a significant influence on this interval $(\mathrm{n}=97$ cows). The last 2 variables are categorical variables measured at 1 time point, with a significant influence on this interval $(\mathrm{n}=91$ cows).

${ }^{2} \mathrm{AGP}=\alpha_{1}$-acid glycoprotein.

${ }^{3}$ The hazard ratio for a $50 \mathrm{ng} / \mathrm{mL}$ increase is shown in this table due to the large magnitude of changes in IGF-I concentrations during the pp period.
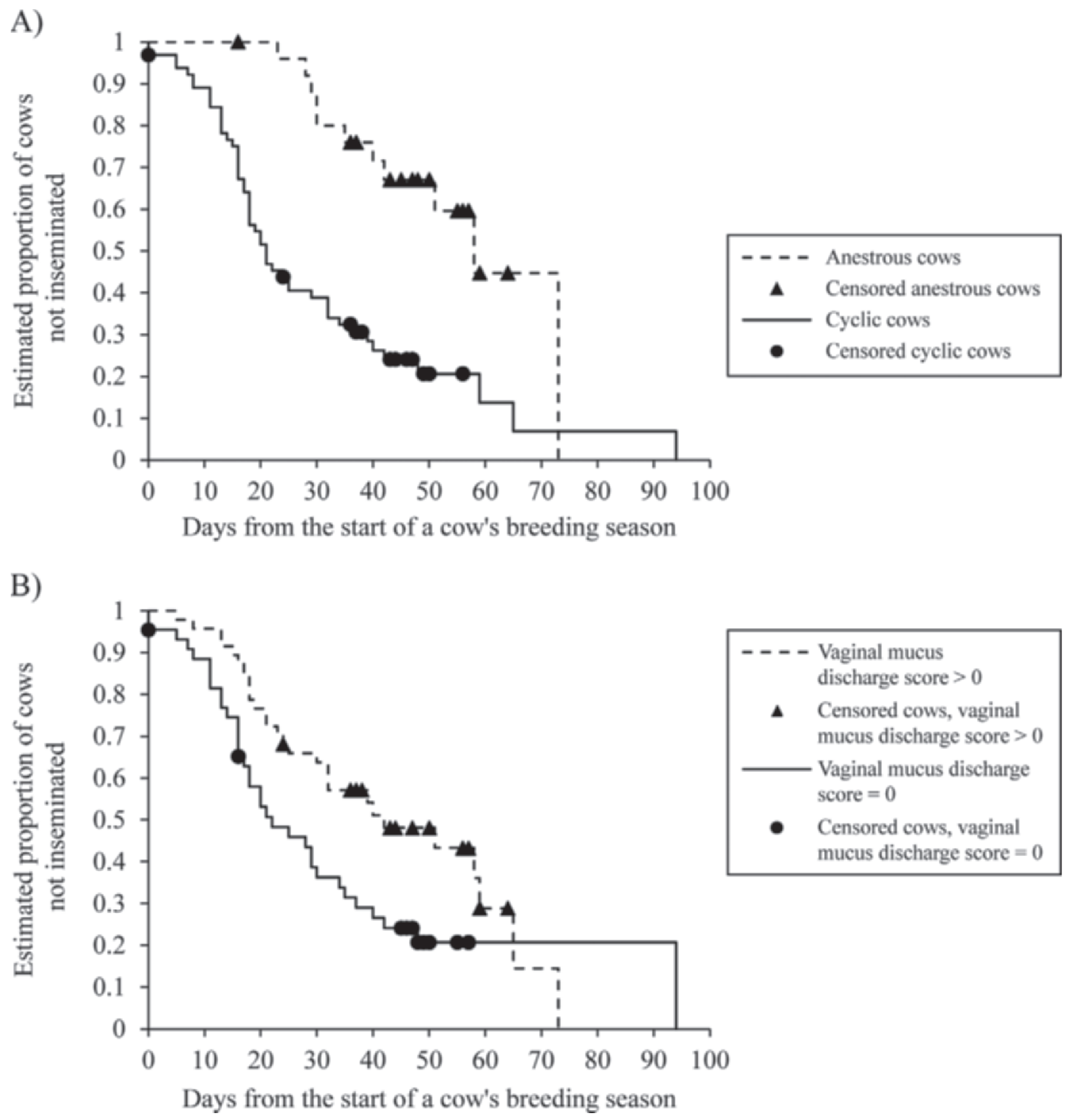

Figure 1. Survival curves of days from the start of a cow's breeding season to first AI in (A) cows that were cyclic or anestrus at the start of their breeding season and $(\mathrm{B})$ cows that did (character score $=0$ ) or did not (character score $>0$ ) have a clear vaginal mucus discharge at d-45 postpartum $(\mathrm{n}=91 \mathrm{cows})$. Censored cows were excluded from further analysis on the date they received either a treatment before AI or had reached the end of the farmer's breeding season without being inseminated. 
Table 6. Proportional regression hazards model of time to a conception leading to a first 30-d positive pregnancy test postcalving after the individual voluntary waiting period for each cow has ended $(\mathrm{n}=81$ cows)

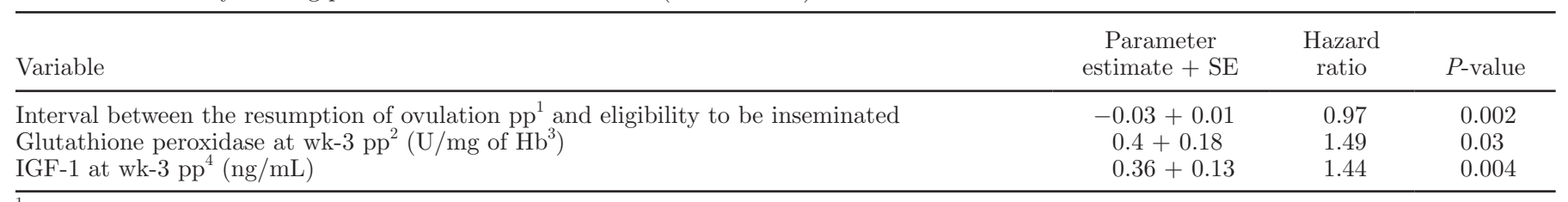

${ }^{1} \mathrm{pp}=$ postpartum.

${ }^{2}$ The hazard ratio for a 25 -unit increase is shown in this table due to the large magnitude of changes in glutathione peroxidase concentrations during the pp period.

${ }^{3} \mathrm{Hb}=$ hemoglobin.

${ }^{4}$ The hazard ratio for a $50 \mathrm{ng} / \mathrm{mL}$ increase is shown in this table due to the large magnitude of changes in IGF-I concentrations during the pp period.

interval from the end of the voluntary waiting period to resumption of ovulation pp increased the probability of having a conception leading to a first 30-d pregnancy by any given time (Table 6 ). The following variables were not found to have an effect on the interval to first conception: NEFA concentration in wk-4 pp $(P=0.24)$ and GGT concentration in wk $4 \mathrm{pp}(P=0.06)$.

\section{What Influences a 30-d Pregnancy Occurring After the First Al?}

Reproductive factors that were associated with the probability of cows conceiving ( $\mathrm{n}=92$ cows; 35 pregnant), based on a 30-d pregnancy diagnosis, were examined. The odds of a positive 30-d pregnancy test tripled for each additional ovulation that cows had before their first AI (odds ratio $=3.17 ; 95 \% \mathrm{CI}=1.7$ to $5.8 ; P=0.0002$ ), if the vaginal mucus sample was clear $4 \mathrm{~d}$ after $\mathrm{AI}$ (odds ratio $=2.99 ; 95 \% \mathrm{CI}=1.06$ to $8.45 ; P=0.03$ ), and if cows had a BCS of 2.75 or 3 at the time of the AI rather than a score of $\leq 2.5$ (odds ratio $=3.01 ; 95 \% \mathrm{CI}=1.07$ to $8.5 ; P=0.03)$. At the time of AI, milk yield $(P=0.95)$, whether cows were lame $(\mathrm{n}=43$ lame cows $)$ or not $(P=0.4)$, SCC $(P=$ $0.3)$, and whether cows had a normal or abnormal $(\mathrm{n}=$ 53 abnormal) uterine ultrasound scan $(P=0.18)$ were not associated with the probability of a $30-\mathrm{d}$ pregnancy occurring. The $\mathrm{c}$ statistic for the area under the ROC curve for this model was 0.814 .

\section{DISCUSSION}

Many papers have been published on the effect of specific endocrine, metabolic, immune, uterine health, and nutritional factors involved in the achievement of key reproductive targets and pregnancy in pp dairy cows. However, what is lacking is an evaluation of the combined effect of all of these variables on the problem of subfertility. Previously, the deleterious effect of subclinical and clinical mastitis (Schrick et al., 2001), low
BCS (Beam and Butler, 1999), and lameness (Lucey et al., 1986) on dairy cow fertility had been confirmed. Furthermore, a synergistic effect between high SCC and lameness in further reducing the proportion of cows that ovulated was also identified (Morris et al., 2009).

Löf et al. (2012) used simulation models to confirm the importance of the concept of the voluntary waiting period in determining herd fertility. They identified 2 reproductive targets that should be monitored: (1) the proportion of cows in the herd that have their first AI during the first $30 \mathrm{~d}$ after the end of the voluntary waiting period and (2) the proportion of cows in the herd pregnant within the first $30 \mathrm{~d}$ after the end of the voluntary waiting period. Using these targets in the present study, cows that had not been inseminated or that failed to conceive were not censored when analysis of the herd's reproductive status was carried out. This would occur if traditional indicators, such as days to first AI pp and days to conception pp, were used.

The following key results were obtained in this study:

\section{Interval to Uterine Involution}

The risk factors in this study that influenced the interval to uterine involution pp included uterine infection, NEB, and disruption to the endocrine and immune systems. Due to lipid mobilization, higher serum NEFA concentrations in wk-1 pp were identified. Resulting from this lipid mobilization, cows that lost $\geq 0.5$ BCS units in the first $4 \mathrm{wk}$ of lactation had a greater risk of failure to achieve normal uterine involution by any given time. Könyves et al. (2009) found an association between a severe decrease in BCS of $\geq 1 \mathrm{U}$, from d 10 to $14 \mathrm{pp}$, until d 28 to $35 \mathrm{pp}$, with the odds of clinical endometritis being present increasing by a factor of 10.8. Wathes et al. (2007) showed that cows with a severe NEB had more severe uterine inflammation, which delayed healing. This study found that higher AGP concentrations in wk-2 pp were related to delayed involution. Previous studies observed that concentra- 
tions of AGP increased in those animals from which uterine pathogens were isolated, particularly Escherichia coli (Sheldon et al., 2001; Williams et al., 2005). Williams et al. (2007) observed that AGP concentrations decreased gradually after parturition until around d-21 pp. Circulating concentrations of acute-phase proteins were found to be related to the severity of disease and the extent of the tissue damage in the affected area (Baumann and Gauldie, 1994). These proteins act at the site of tissue damage to limit further injury and promote uterine repair.

Higher concentrations of IGF-I in wk-3 pp were related to a shorter interval to uterine involution. The IGF-I receptor is expressed in the uterus and may be involved in involution (Llewellyn et al., 2008). At 2 wk pp, IGF-I mRNA was present in the subepithelial stroma of intercaruncular and caruncular endometrium of both uterine horns. As IGF-I stimulates cell proliferation and collagen synthesis, it was thought that the IGF-I produced in this region may act in an autocrine or paracrine manner, or both, to stimulate the proliferation of uterine stroma and epithelium during uterine involution (Llewellyn et al., 2008; Foley et al., 2012). Wathes et al. (2011) found that cows in severe NEB had altered IGF-signaling pathways in the endometrium, which might affect the rate of repair of the endometrial epithelium. Cows in severe NEB, compared with cows in mild NEB, had more severe or prolonged uterine inflammation and impaired tissue repair (both measured by gene expression; Wathes, 2012). By using survival analysis in the present study, no scope existed to build in repeated measurements of variables as can be done with linear regression, unless cows with censored data were excluded. To minimize correlation, the analysis of each variable was carried out separately for each week. From the literature, it has been observed that by d 25 , superficial regeneration of the endometrium occurs (Sheldon, 2004) in the healthy cow without uterine disease. Therefore, from a physiological point of view, it is interesting that IGF-I concentration in wk 3 was found to be significant. It has been confirmed in the literature that treatment of clinical endometritis before wk-4 pp had no benefit on time to pregnancy (LeBlanc et al., 2002). Thus, the status of cows IGF-I levels in wk-3 pp could be used to determine whether treatment in wk 4 would be required.

At calving, cows with a shorter interval to involution had higher GLDH concentrations, indicative of the fact that their liver was capable of coping with a heavier metabolic load (i.e., gluconeogenesis, IGF-I production, and FA oxidation) than cows with a longer interval to involution. Hachenberg et al. (2007) identified prepartum cows with NEFA concentrations of $\leq 0.5 \mathrm{~m} M$ as being more likely to be healthy pp. These cows had higher weekly GLDH concentrations prepartum up to the time of calving compared with their unhealthy equivalents. The liver of the healthy cows was considered to be more adaptable to changes in metabolic status.

The present study also found that an increase in concentrations of neutrophils and GPX were associated with an increased probability of involution. Previously, it was found that neutrophils recovered from seleniumdeficient cattle were able to ingest pathogens in vitro, but were less effective in killing them compared with neutrophils from selenium-sufficient animals (Boyne and Arthur, 1986; Turner and Finch, 1991). Selenium may reduce the development of oxidative stress, due to its antioxidant effect (Bernabucci et al., 2002). This development occurs when neutrophils phagocytize and digest microbes (Sordillo and Aitken, 2009). The antioxidant system reduces free radicals to prevent them from damaging cells, such as neutrophils. The important interrelationship between selenium and the killing ability of neutrophils would influence the speed of resolution of postpartum uterine infections and, hence, the length of time to uterine involution postpartum. Glutathione peroxidase provides a reliable test for determination of blood selenium status in cattle (Koller et al., 1984). The quantitative relationship between normal concentrations of whole-blood selenium $(>0.07$ $\mathrm{mg} / \mathrm{kg}$ ) and its equivalent GPX $[25-500 \mathrm{U} / \mathrm{mg}$ of hemoglobin $(\mathbf{H b})$ per min], between marginal deficiency of selenium (0.05-0.06 mg/kg) and its equivalent GPX (15-25 U/mg of $\mathrm{Hb}$ per min), and between deficiency of selenium (0.01-0.04 mg/kg) and its equivalent GPX (0-15 U/mg of $\mathrm{Hb}$ per min) has been determined (Maas and Valberg, 2009). These numeric relationships are laboratory specific and interpretation must account for these differences.

In the current study, it was found that elevated insulin concentrations in wk 1 and $2 \mathrm{pp}$ were related to a delay in involution. However, the time of collection of the blood samples may have influenced the insulin profile. All blood samples were collected after cows had received concentrates during milking. Thus, the same variable was used for all cows, namely insulin concentration postfeeding concentrate. The variable could not have been used if some cows had been bled before and the remainder after milking. A postprandial peak in blood insulin concentration occurs about $1 \mathrm{~h}$ postfeeding and a return to preprandial concentration occurs 4 $\mathrm{h}$ after feeding (Blum et al., 2000).

\section{Interval to First pp Ovulation}

In this study, the interval to first ovulation pp was shorter in cows with higher serum $\mathrm{T}_{3}$ concentration during the early pp period as previously reported by 
Reist et al. (2003). Circulating thyroxine $\left(\mathrm{T}_{4}\right)$ concentrations are converted to $\mathrm{T}_{3}$ and reflect the thyroid and iodine status of the animal $(>50 \mathrm{nmol} / \mathrm{L}=$ normal; $<$ $20 \mathrm{nmol} / \mathrm{L}=$ abnormal). Thus, they are useful in the diagnosis of deficiency. Low concentrations of thyroid hormones delay the occurrence of the first ovulation and the first detected estrus in cows (Huszenicza et al., 2006). About $46 \%$ of infertile human patients with hypothyroidism exhibit hyperprolactinemia (Goswami et al., 2009). Hyperprolactinemia occurs due to the prolactin-stimulating action of thyrotropin-releasing hormone. Hyperprolactinemia impairs the pulsatile secretion of GnRH and, hence, interferes with the occurrence of ovulation (Zollner et al., 2001; Poppe and Velkeniers, 2003). Thyroid supplementation restores prolactin levels and normalizes ovulatory function. Thyroid hormones are essential for maturation of large antral follicles selected for ovulation in cattle (Sato and Jiang, 2001; Ashkar et al., 2010). It is thought that a state of hypothyroidism may develop as a consequence of NEB (Pethes et al., 1985). Care must be taken in interpretation of $\mathrm{T}_{4}$ values, as natural variation exists according to stage of lactation, with concentrations being much lower in early lactation, season, age of animal, and so on (Scott, 2014). Another study observed that, during the first $3 \mathrm{wk}$ pp, clinically healthy cows had higher concentrations $(P<0.05)$ of both $\mathrm{T}_{4}(45.75 \pm$ $14.27 \mathrm{nmol} / \mathrm{L})$ and $\mathrm{T}_{3}(2.22 \pm 0.74)$ compared with unhealthy cows with clinical ketosis (Djoković et al., 2010). Triiodothyronine would be a useful biomarker for the identification of cows, as early as wk $2 \mathrm{pp}$, that might be susceptible to longer anovulatory periods pp.

Previous research has identified an association between both energy balance and uterine inflammation with time to resumption of ovulation pp (Dubuc et al., 2012). The study found that resumption of ovulation by d 21 pp was associated with parity, season of calving, lower NEFA concentrations from $1 \mathrm{wk}$ before to $3 \mathrm{wk}$ after parturition, lower BHBA concentrations through wk 1 to 3 postpartum, and lower haptoglobin concentrations through wk 1 to $2 \mathrm{pp}$ than cows that had not resumed ovulation by d-63 pp. A delay in resumption of ovulation beyond d $63 \mathrm{pp}$ was associated with season of calving, the presence of cytological endometritis at d-35 pp ( $\geq 6 \%$ PMNL in endometrial cytology), and higher haptoglobin concentrations between d 15 to $21 \mathrm{pp}$. The present study found that both a severe loss in BCS and lower serum IGF-I concentrations early pp resulted in a delay in resumption of ovulation. In cattle, IGF-I is mainly released from the liver in response to $\mathrm{GH}$, binding to GH receptors in the liver. It is also secreted by granulosa cells and theca interna cells of developing follicles (Schams et al., 2002). With severe BCS loss, the GH-IGF axis is uncoupled, due to a down- regulation of the $\mathrm{GH}$ receptor in the liver, resulting in decreased IGF-I concentrations. A decrease in IGF-I concentration is associated with increased atresia of the dominant follicle and reduced estradiol production (Lucy et al., 1992; Butler et al., 2004). Negative energy balance is linked with decreased GnRH pulse frequency and, hence, reduced LH pulses from the pituitary gland (Schillo, 1992). As glucose is a preferred substrate for neuronal energy metabolism, an inadequate supply inhibits the GnRH pulse generator (Schneider, 2004).

\section{Prolonged Luteal Phase}

This study's finding that the presence of a clear vaginal mucus discharge at the time of the first pp ovulation improved the odds of having a normal luteal phase is in agreement with another study (Opsomer et al., 2000). The development of a prolonged luteal phase can occur if cows with uterine infections ovulate. Lipopolysaccharide, the endotoxin produced by $E$. coli, has been identified in plasma of cows with uterine infection pp (Sheldon et al., 2002; Mateus et al., 2003). Cells of the endometrium express the specific receptor complex for detection of LPS, and LPS switches the main production of prostaglandin secretion from $\mathrm{PGF}_{2 \alpha}$ to $\mathrm{PGE}_{2}$, thereby delaying the occurrence of luteolysis (Herath et al., 2006; Sheldon et al., 2009). Previously, elevated concentrations of the acute phase-protein AGP have been associated with increased growth density of recognized uterine pathogens (Williams et al., 2005).

During the transition from pregnancy to lactation, homeorhetic adaptations are coordinated across almost every organ and are marked by changes in hormones and metabolism to accommodate the increased energy demands of lactation (Casey and Plaut, 2012). The increased energy demands are associated with increased lipolysis, leading to NEFA production. Acetyl-CoA, produced by oxidation of NEFA in the liver (Herdt and Emery, 1992), stimulates the Krebs cycle to provide energy for gluconeogenesis (Ingvartsen, 2006). AcetylCoA can also be converted to acetoacetate from which BHBA and acetone are produced. Thus, higher serum concentrations of BHBA, indicative of NEB, occur during the first 3 to 4 wk pp (Herdt, 2000). Higher concentrations of BHBA were previously associated with lower neutrophil blood counts and negatively associated with the ability of neutrophils to phagocytize bacteria to form extracellular traps and kill bacteria (Grinberg et al., 2008). Lower neutrophil counts reduced the ability of the innate immune system to fight infection. In the present study, the liver enzyme GGT concentration was higher in cows with normal luteal phases. Stojević et al. (2005) noted that this high concentration demonstrated the ability of healthy Holstein cows to cope with the 
high metabolic clearance rate through the liver during the first $45 \mathrm{~d}$ pp.

\section{Interval to First AI}

The current study showed that a prolonged interval to first AI occurred in cows that had not resumed ovulatory cycles by the start of their breeding seasons. Thatcher and Wilcox (1973) showed that fertility was influenced by the number of estrous cycles that occur between calving and first AI. This study identified that a vaginal discharge with a character score $>0$ or uterine infection (abnormal uterine ultrasound scan) at d-45 pp delayed the time to first AI. Williams et al. (2007) observed an association between a slower growing first pp dominant follicle and the presence of $E$. coli in the uterus. When fully developed, these follicles produced lower circulating concentrations of estradiol (Sheldon et al., 2002). A further study showed that an intrauterine administration of LPS was followed by normal LH pulse profiles. It was postulated that LPS reduced LH receptors on follicular granulosa cells, thus inhibiting the response to LH and thereby preventing ovulation (Williams et al., 2008).

The present study found that lower concentrations of AGP in wk $3 \mathrm{pp}$ were associated with a shortened interval to AI. The severity of uterine bacterial contamination, as determined by the bacterial growth density, has been shown to be correlated with the peripheral circulating concentrations of AGP (Sheldon et al., 2001). Concentrations of AGP were increased in cows where E. coli was isolated from the uterus, but not other bacteria. Fewer of these cows ovulated.

The present study found that lower concentrations of AGP in wk 3 pp were associated with a shortened interval to AI. The severity of uterine bacterial contamination, as determined by the bacterial growth density, is correlated with the peripheral circulating concentrations of AGP (Sheldon et al., 2001). Concentrations of AGP were increased in cows where $E$. coli was isolated from the uterus, but not other bacteria. Escherichia coli was associated with a slower growing first dominant follicle pp with lower production of estradiol by its granulosa cells at the time of maximum follicle diameter (Williams et al., 2007). The reduction in estradiol was caused by downregulation of the aromatase enzyme after the cells were exposed to the $E$. coli endotoxin LPS. Thus, fewer of these cows ovulated.

Higher concentrations of IGF-I in wk 3 pp were associated with a shorter interval to AI in the present study. As previously discussed, IGF-I is associated with the rate of repair of the reproductive tract pp during involution (Llewellyn et al., 2008). The transient postpartum period of NEB, which, according to Butler
(2003), reaches a nadir at $10 \mathrm{~d}$ pp, can persist for up to 10 to 12 wk pp, depending on feed intake and milk yield. During this period of NEB, an uncoupling of the GH-IGF-I axis occurs, with a resultant decrease in peripheral circulating IGF-I concentrations. Mourkioti and Rosenthal (2005) noted that IGF-1 had a positive effect on tissue repair mechanisms following injury. Wathes (2012) observed that cows in severe NEB had more severe or prolonged uterine inflammation and impaired tissue repair. Cows with either clinical or subclinical endometritis had longer intervals from calving to first insemination (Sheldon et al., 2008).

\section{Interval to Conception from the End of the Voluntary Waiting Period}

This study found that higher blood concentrations of IGF-I and GPX in wk 3 and a shorter interval to first ovulation decreased the interval to conception. Under conditions of low IGF-I concentrations, dominant follicles may fail to reach ovulatory size and thus produce insufficient estradiol concentrations to induce ovulation (Taylor et al., 2004). Konigsson et al. (2008) observed that cows with significantly higher circulating IGF-I concentrations during the first 2 wk pp resumed ovarian activity within the first 7 wk pp. Shrestha et al. (2004) reported that cows with normal ovarian cycles (resumption of ovulation $\leq 45 \mathrm{~d} \mathrm{pp}$ ) had significantly shorter intervals from calving to conception $(131 \pm 9.8$ d) compared with cows that were anovulatory (first pp ovulation occurred $>45 \mathrm{~d}$ after calving; $181 \pm 8.3 \mathrm{~d}$; $P$ $=0.03)$. A shorter interval to first ovulation resulted in more ovulatory cycles before first AI (Butler and Smith, 1989), which, in turn, improved the conception rate. Improved conception rate occurred due to peripheral $\mathrm{P}_{4}$ concentrations increasing during the first 2 to 3 ovulations pp (Villa-Godoy et al., 1988; Spicer et al., 1990; Staples et al., 1990).

In agreement with the present study, Kommisrud et al. (2005) found that selenium supplementation decreased the interval to conception. The antioxidant selenium can be effective in reducing oxidative stress and the severity of several proinflammatory-based dairy cattle diseases, such as mastitis and metritis (Spears and Weiss, 2008; Sordillo and Aitken, 2009). Selenium is incorporated into a family of proteins called selenoproteins. These proteins can reduce the toxic reactive oxygen species produced by neutrophils to less reactive molecules, and regulate intercellular signaling pathways that lead to inflammatory gene expression (Huang et al., 2012). An intramuscular injection of selenium with vitamin $\mathrm{E}$ reduces the interval from calving to conception (Aréchiga et al., 1994) due to the synergistic action of both antioxidants. 


\section{Factors Affecting Conception Rate After the First Al}

An increase in conception rate is a major factor influencing reproductive efficiency in dairy cows. The present study found that more previous ovulations, a BCS of 2.75 or 3 rather than $\leq 2.5$, and a noninfected vaginal mucus discharge on d 4 after first AI, were risk factors for a 30-d pregnancy following first AI pp. Clear evidence exists that an increased number of ovulatory cycles in the pp period before first AI increases the conception rate (Walsh et al., 2007). More ovulatory cycles before the first AI (Thatcher and Wilcox, 1973; Allrich, 1994; Darwash et al. 1997) would provide priming of the brain by $\mathrm{P}_{4}$ and uterine clearance during estrus. In agreement with Cummins et al. (2012), the current study found an association between lower BCS at the time of AI and poorer conception rate. Cummins et al. (2012) found that cows selected genomically for higher fertility maintained a higher BCS throughout lactation and had higher milk yields compared with low-fertility cows.

The present study found that the probability of conception after first AI was higher if the vaginal mucus discharge was clear on d 4 after AI. This is in agreement with a previous study that showed that conception rates in cows (between 50 and $65 \mathrm{~d}$ after $\mathrm{AI}$ ), but not in heifers, were significantly reduced if an abnormal cervical mucus discharge (opaque mucus or either mucus containing flecks of pus, purulent mucus, or mucopurulent material) was present at the time of AI (Ata et al., 2010). It has also being shown that, on ovulation, the smaller dominant follicles associated with uterine $E$. coli infections formed smaller CL. These CL produced lower peripheral concentrations of $\mathrm{P}_{4}$ on $\mathrm{d} 5$ to 7 postovulation compared with cows with noninfected uterine tracts (Williams et al. 2007). In crossbred beef heifers, low serum $\mathrm{P}_{4}$ concentrations have been shown to alter the normal temporal changes that occur in the expression of genes in the endometrium, mainly by delaying their expression (Forde et al., 2011). This delay in temporal changes in endometrial gene expression was associated with a reduced capacity of the uterus to support conceptus development.

\section{CONCLUSIONS}

Fertile cows achieved their reproductive targets earlier. In the first $4 \mathrm{wk} p \mathrm{p}$, the following was noted. Their liver was capable of coping with an increased metabolic load, as evidenced by increased circulating concentrations of the liver enzymes GLDH (at calving) and GGT (4 wk pp). Their immune system response was associated with an earlier interval to uterine involution pp. They did not experience a severe NEB or a decrease in hormone production and had an adequate intake of selenium and magnesium. These cows were more likely to have a 30-d pregnancy after their first AI because of an earlier resumption of estrous cycles pp, ensuring that more ovulations had occurred before this AI. At the time of the first AI, they were not in a state of NEB and they had a clear vaginal mucus discharge on d 4 after the AI. Finally, from a management point of view, this study identified that higher circulating concentrations of IGF-I in wk 3 pp was a biomarker of fertility being associated with a shorter interval to (1) uterine involution pp, (2) first AI, and (3) conception leading to a 30-d pregnancy. Higher IGF-I in wk 4 pp was associated with a shorter interval to resumption of ovulation pp.

\section{ACKNOWLEDGMENTS}

This study was funded from a Science Foundation Ireland (Dublin, Ireland) grant (07/SRC/B1156). The authors thank the staff and owner of the farm involved in the trial for their support and assistance. Special thanks go to the University College Dublin (UCD) Reproductive Biology Research Cluster team (Belfield, Dublin, Ireland) for their help during the field work. Special thanks also go to Fiona Carter and Pat Duffy of UCD Lyons Research Farm (Co. Kildare, Ireland), and the staff in the hormone assay and clinical pathology laboratories (UCD Veterinary Sciences Centre) for their expert technical assistance. The authors thank Morgan Sheehy (UCD School of Veterinary Medicine, Dublin, Ireland) for carrying out body condition and lameness scoring of the herd during the trial.

\section{REFERENCES}

Allrich, R. D. 1994. Endocrine and neural control of estrus in dairy cows. J. Dairy Sci. 77:2738-2744.

Aréchiga, C. F., O. Ortíz, and P. J. Hansen. 1994. Effect of prepartum injection of vitamin $\mathrm{E}$ and selenium on postpartum reproductive function of dairy cattle. Theriogenology 41:1251-1258.

Ashkar, F. A., P. M. Bartlewski, J. Singh, P. S. Malhi, K. M. Yates, T. Singh, and W. A. King. 2010. Thyroid hormone concentrations in systemic circulation and ovarian follicular fluid of cows. Exp. Biol. Med. (Maywood) 235:215-221.

Ata, A., H. Türütoğlu, M. Kale, M. Ş. Gülay, and F. Pehlivanoğlu. 2010. Microbial flora of normal and abnormal cervical mucous discharge associated with reproductive performance of cows and heifers in estrus. Asian-australas. J. Anim. Sci. 23:1007-1012.

Baumann, H., and J. Gauldie. 1994. The acute phase response. Immunol. Today 15:74-80.

Beam, S. W., and W. R. Butler. 1999. Effects of energy balance on follicular development and first ovulation in postpartum dairy cows. J. Reprod. Fertil. Suppl. 54:411-424.

Beltman, M. E., N. Forde, P. Furney, F. Carter, J. F. Roche, and P. Lonergan. 2010. Characterization of endometrial gene expression and metabolic parameters in beef heifers yielding viable or nonviable embryos on day 7 after insemination. Reprod. Fertil. Dev. 22:987-999. 
Bernabucci, U., B. Ronchi, N. Lacetera, and A. Nardone. 2002. Markers of oxidative status in plasma and erythrocytes of transition dairy cows during hot season. J. Dairy Sci. 85:2173-2179.

Blum, J. W., R. M. Bruckmaier, P.-Y. Vacher, A. Münger, and F. Jans. 2000. Twenty-four-hour patterns of hormones and metabolites in week 9 and 19 of lactation in high-yielding dairy cows fed triglycerides and free fatty acids. J. Vet. Med. A Physiol. Pathol. Clin. Med. 47:43-60.

Borsberry, S., and H. Dobson. 1989. Periparturient diseases and their effect on reproductive performance in five dairy herds. Vet. Rec. 124:217-219.

Boyne, R., and J. R. Arthur. 1986. The response of selenium deficient mice to Candida albicans infection. J. Nutr. 116:816-822.

Butler, S. T., S. H. Pelton, and W. R. Butler. 2004. Insulin increases $17 \beta$-estradiol production by the dominant follicle of the first postpartum follicle wave in dairy cows. Reproduction 127:537-545.

Butler, W. R. 2000. Nutritional interactions with reproductive performance in dairy cattle. Anim. Reprod. Sci. 60-61:449-457.

Butler, W. R. 2003. Energy balance relationships with follicular development, ovulation and fertility in postpartum dairy cows. Livest. Prod. Sci. 83:211-218.

Butler, W. R., and R. D. Smith. 1989. Interrelationships between energy balance and postpartum reproductive function in dairy cattle. J. Dairy Sci. 72:767-783.

Casey, T. M., and K. Plaut. 2012. Lactation Biology Symposium: Circadian clocks as mediators of the homeorhetic response to lactation. J. Anim. Sci. 90:744-754.

Collett, D. 1994. Modeling Survival Data in Medical Research. Chapman and Hall, London, UK.

Cummins, S. B., P. Lonergan, A. C. O. Evans, D. P. Berry, R. D Evans, and S. T. Butler. 2012. Genetic merit for fertility traits in Holstein cows: I. Production characteristics and reproductive efficiency in a pasture-based system. J. Dairy Sci. 95:1310-1322.

Darwash, A. O., G. E. Lamming, and J. A. Woolliams. 1997. The phenotypic association between the interval to postpartum ovulation and traditional measures of fertility in dairy cattle. Anim. Sci. 65:9-16.

Del Vecchio, R. P., D. J. Matsas, S. Fortin. D. P. Sponenberg, and G. S. Lewis. 1994. Spontaneous uterine infections are associated with elevated prostaglandin $\mathrm{F}_{2 \alpha}$ metabolite concentrations in postpartum dairy cows. Theriogenology 41:413-421.

Diskin, M. G. 2008. Reproductive management of dairy cows: A review (Part 11). Ir. Vet. J. 61:403-411.

Djoković, R., H. Šamanc, J. Bojkovski, and N. Fratrić. 2010. Blood concentrations of thyroid hormones and lipids of dairy cows in transitional period. Lucrări Ştiintifice Medicină Veterinară 43:3440.

Dubuc, J., T. F. Duffield, K. E. Leslie, J. S. Walton, and S. J. LeBlanc. 2012. Risk factors and effects of postpartum anovulation in dairy cows. J. Dairy Sci. 95:1845-1854.

Edmonson, A. J., I. J. Lean, L. D. Weaver, T. Farver, and G. Webster. 1989. A body condition scoring chart for Holstein dairy cows. J. Dairy Sci. 72:68-78.

Foley, C., A. Chapwanya, C. J. Creevey, F. Narciandi, D. Morris, E. M. Kenny, P. Cormican, J. J. Callanan, C. O'Farrelly, and K. G. Meade. 2012. Global endometrial transcriptomic profiling: Transient immune activation precedes tissue proliferation and repair in healthy beef cows. BMC Genomics 13:489-501.

Fonseca, F. A., J. H. Britt, B. T. McDaniel, J. C. Wilk, and A. H. Rakes. 1983. Reproductive traits of Holsteins and Jerseys. Effects of age, milk yield, and clinical abnormalities on involution of cervix and uterus, ovulation, estrous cycles, detection of estrus, conception rate, and days open. J. Dairy Sci. 66:1128-1147.

Forde, N., M. E. Beltman, G. B. Duffy, P. Duffy, J. P. Mehta, P. O'Gaora, J. F. Roche, P. Lonergan, and M. A. Crowe. 2011. Changes in the endometrial transcriptome during the bovine estrous cycle: Effect of low circulating progesterone and consequences for conceptus elongation. Biol. Reprod. 84:266-278.

Galvão, K. N., M. Frajblat, W. R. Butler, S. B. Brittin, C. L. Guard, and R. O. Gilbert. 2010. Effect of early postpartum ovulation on fertility in dairy cows. Reprod. Domest. Anim. 45:e207-e211.
Gier, H. T., and G. B. Marion. 1968. Uterus of the cow after parturition: Involutional changes. Am. J. Vet. Res. 29:83-96.

Goswami, B., S. Patel, M. Chatterjee, B. C. Koner, and A. Saxena. 2009. Correlation of prolactin and thyroid hormone concentration with menstrual patterns in infertile women. J. Reprod. Infertil. 10:207-212.

Grinberg, N., S. Elazar, I. Rosenshine, and N. Y. Shpigel. 2008. $\beta$-Hydroxybutyrate abrogates formation of bovine neutrophil extracellular traps and bactericidal activity against mammary pathogenic Escherichia coli. Infect. Immun. 76:2802-2807.

Hachenberg, S., C. Weinkauf, S. Hiss, and H. Sauerwein. 2007. Evaluation of classification modes potentially suitable to identify metabolic stress in healthy dairy cows during the peripartal period. J. Anim. Sci. 85:1923-1932.

Herath, S., D. P. Fischer, D. Werling, E. J. Williams, S. T. Lilly, H. Dobson, C. E. Bryant, and I. M. Sheldon. 2006. Expression and function of toll-like receptor 4 in the endometrial cells of the uterus. Endocrinology 147:562-570.

Herath, S., S. T. Lilly, D. P. Fischer, E. J. Williams, H. Dobson, C. E. Bryant, and I. M. Sheldon. 2009. Bacterial lipopolysaccharide induces an endocrine switch from prostaglandin $\mathrm{F}_{2 \alpha}$ to prostaglandin $\mathrm{E}_{2}$ in bovine endometrium. Endocrinology 150:1912-1920.

Herdt, T. H. 2000. Ruminant adaptation to negative energy balance. Vet. Clin. North Am. Food Anim. Pract. 16:215-230.

Herdt, T. H., and R. S. Emery. 1992. Therapy of diseases of ruminant intermediary metabolism. Vet. Clin. North Am. Food Anim. Pract. 8:91-106.

Hersom, M. J., R. P. Wettemann, C. R. Krehbiel, G. W. Horn, and D. H. Keisler. 2004. Effect of live weight gain of steers during winter grazing: III. Blood metabolites and hormones during feedlot finishing. J. Anim. Sci. 82:2059-2068.

Huang, Z., A. H. Rose, and P. R. Hoffmann. 2012. The role of selenium in inflammation and immunity: From molecular mechanisms to therapeutic opportunities. Antioxid. Redox Signal. 16:705-743.

Huszenicza, G. Y., M. Kulcsár, P. Kóródi, J. Bartyik, P. Rudas, P. Ribiczei-Szabó, J. A. Nikolić, H. Šamanc, I. Ivanov, and D. Gvozdić. 2006. Adrenocortical and thyroid function, hormone and metabolite profiles and the onset of ovarian cyclicity in dairy cows suffering from various forms of ketosis. Acta Vet. (Beogr.) $56: 25-36$.

Ingvartsen, K. L. 2006. Feeding and management related diseases in the transition cow: Physiological adaptations around calving and strategies to reduce feeding related diseases. Anim. Feed Sci. Technol. 126:175-213.

Koller, L. D., P. J. South, J. H. Exon, G. A. Whitbeck, and J. Maas. 1984. Comparison of selenium levels and glutathione peroxidase activity in bovine whole blood. Can. J. Comp. Med. 48:431-433.

Kommisrud, E., O. Østerås, and T. Vatn. 2005. Blood selenium associated with health and fertility in Norwegian dairy herds. Acta Vet. Scand. 46:229-240.

Konigsson, K., G. Savoini, N. Govoni, G. Invernizzi, A. Prandi, H. Kindahl, and M. C. Veronesi. 2008. Energy balance, leptin, NEFA and IGF-I plasma concentrations and resumption of post partum ovarian activity in Swedish red and white breed cows. Acta Vet. Scand. 50:3

Könyves, L., O. Szenci, V. Jurkovich, L. Tegzes, A. Tirián, N. Solymosi, G. Gyulay, and E. Brydl. 2009. Risk assessment of postpartum uterine disease and consequences of puerperal metritis for subsequent metabolic status, reproduction and milk yield in dairy cows. Acta Vet. Hung. 57:155-169.

LeBlanc, S. J. 2008. Postpartum uterine disease and dairy herd reproductive performance: A review. Vet. J. 176:102-114.

LeBlanc, S. J., T. F. Duffield, K. E. Leslie, K. G. Bateman, G. P. Keefe, J. S. Walton, and W. H. Johnson. 2002. The effect of treatment of clinical endometritis on reproductive performance in dairy cows. J. Dairy Sci. 85:2237-2249.

Lindell, J.-O., H. Kindahl, L. Jansson, and L.-E. Edqvist. 1982. Postpartum release of prostaglandin $\mathrm{F}_{2 \alpha}$ and uterine involution in the cow. Theriogenology 17:237-245.

Llewellyn, S., R. Fitzpatrick, D. A. Kenny, J. Patton, and D. C. Wathes. 2008. Endometrial expression of the insulin-like growth 
factor system during uterine involution in the postpartum dairy cow. Domest. Anim. Endocrinol. 34:391-402.

Löf, E., H. Gustafsson, and U. Emanuelson. 2012. Evaluation of two dairy herd reproductive performance indicators that are adjusted for voluntary waiting period. Acta Vet. Scand. 54:5-15.

Lucey, S., G. J. Rowlands, and A. M. Russell. 1986. The association between lameness and fertility in dairy cows. Vet. Rec. 118:628 631

Lucy, M. C., J. Beck, C. R. Staples, H. H. Head, R. L. De La Sota, and W. W. Thatcher. 1992. Follicular dynamics, plasma metabolites, hormones and insulin-like growth factor I (IGF-I) in lactating cows with positive or negative energy balance during the preovulatory period. Reprod. Nutr. Dev. 32:331-341.

Maas, J., and S. J. Valberg. 2009. Nutritional and toxic rhabdomyolysis. Page 1406 in Large Animal Internal Medicine. 4th rev. ed. Mosby, St. Louis, MO.

Madej, A., H. Kindahl, W. Woyno, L.-E. Edqvist, and R. Stupnicki. 1984. Blood levels of 15-keto-13,14-dihydroprostaglandin $\mathrm{F}_{2 \alpha}$ during the postpartum period in primiparous cows. Theriogenology $21: 279-287$.

Mateus, L., L. L. da Costa, F. Bernardo, and J. R. Silva. 2002. Influence of puerperal uterine infection on uterine involution and postpartum ovarian activity in dairy cows. Reprod. Domest. Anim. $37: 31-35$.

Mateus, L., L. Lopes da Costa, P. Diniz, and A. J. Ziecik. 2003. Relationship between endotoxin and prostaglandin (PGE2 and PGFM) concentrations and ovarian function in dairy cows with puerperal endometritis. Anim. Reprod. Sci. 76:143-154.

Mee, J. F., F. Buckley, D. Ryan, and P. Dillon. 2009. Pre-breeding ovario-uterine ultrasonography and its relationship with first service pregnancy rate in seasonal-calving dairy herds. Reprod. Domest. Anim. 44:331-337.

Morris, M. J., S. L. Walker, D. N. Jones, J. E. Routly, R. F. Smith and H. Dobson. 2009. Influence of somatic cell count, body condition and lameness on follicular growth and ovulation in dairy cows. Theriogenology 71:801-806.

Mourkioti, F., and N. Rosenthal. 2005. IGF-I, inflammation and stem cells: Interactions during muscle regeneration. Trends Immunol. 26:535-542.

Opsomer, G., Y. T. Gröhn, J. Hertl, M. Coryn, H. Deluyker, and A. de Kruif. 2000. Risk factors for post-partum ovarian dysfunction in high producing dairy cows in Belgium: A field study. Theriogenology 53:841-857.

Pethes, G, J. Bokori, P. Rudas, V. L. Frenyó, and S. Fekete. 1985. Thyroxin, triiodothyronine, reverse-triiodothyronine, and other physiological characteristics of periparturient cows fed restricted energy. J. Dairy Sci. 68:1148-1154.

Poppe, K., and B. Velkeniers. 2003. Thyroid disorders in infertile women. Ann. Endocrinol. (Paris) 64:45-50.

Reimers, T. J., R. G. Cowan, J. P. McCann, and M. W. Ross. 1982. Validation of a rapid solid-phase radioimmunoassay for canine, bovine and equine insulin. Am. J. Vet. Res. 43:1274-1278.

Reist, M., D. K. Erdin, D. von Euw, K. M. Tschümperlin, H. Leuenberger, H. M. Hammon, C. Morel, C. Philipona, Y. Zbinden, N. Künzi, and J. W. Blum. 2003. Postpartum reproductive function: Association with energy, metabolic and endocrine status in high yielding dairy cows. Theriogenology 59:1707-1723.

Rodriguez-Martinez, H., J. Ko, D. McKenna, P. G. Weston, H. L. Whitmore, B. K. Gustafsson, and W. C. Wagner. 1987. Uterine motility in the cow during the estrus cycle. II. Comparative effects of prostaglandins F2a, E2, and cloprostenol. Theriogenology $27: 349-358$.

Royal, M. D., A. O. Darwash, A. P. F. Flint, R. Webb, J. A. Woolliams, and G. E. Lamming. 2000. Declining fertility in dairy cattle: Changes in traditional and endocrine parameters of fertility. Anim. Sci. 70:487-501.

Sato, E., and J. Y. Jiang. 2001. Follicular development and ovulation in hypothyroid rdw rats. Ital. J. Anat. Embryol. 106(Suppl. 2):249-256

Schams, D., B. Berisha, M. Kosmann, and W. M. Amselgruber. 2002. Expression and localization of IGF family members in bovine an- tral follicles during final growth and in luteal tissue during different stages of estrous cycle and pregnancy. Domest. Anim. Endocrinol. 22:51-72.

Schepers, A. J., T. J. G. M. Lam, Y. H. Schukken, J. B. M. Wilmink, and W. J. A. Hanekamp. 1997. Estimation of variance components for somatic cell counts to determine thresholds for uninfected quarters. J. Dairy Sci. 80:1833-1840.

Schillo, K. K. 1992. Effects of dietary energy on control of luteinizing hormone secretion in cattle and sheep. J. Anim. Sci. 70:12711282 .

Schneider, J. E. 2004. Energy balance and reproduction. Physiol. Behav. 81:289-317.

Schrick, F. N., M. E. Hockett, A. M. Saxton, M. J. Lewis, H. H. Dowlen, and S. P. Oliver. 2001. Influence of subclinical mastitis during early lactation on reproductive parameters. J. Dairy Sci. 84:1407-1412

Scott, P. 2014. Trace element deficiency in cattle. Accessed Jan. 5, 2014. http://www.nadis.org.uk/bulletins/trace-element-deficiency-in-cattle.aspx.

Scully, S., V. Maillo, P. Duffy, A. K. Kelly, M. A. Crowe, D. Rizos, and P. Lonergan. 2013. The effect of lactation on post-partum uterine involution in Holstein dairy cows. Reprod. Domest. Anim. 48:888-892. 10.1111/rda.12181.

Sheldon, I. M. 2004. The postpartum uterus. Vet. Clin. North Am Food Anim. Pract. 20:569-591.

Sheldon, I. M., J. Cronin, L. Goetze, G. Donofrio, and H.-J. Schuberth. 2009. Defining postpartum uterine disease and the mechanisms of infection and immunity in the female reproductive tract in cattle. Biol. Reprod. 81:1025-1032.

Sheldon, I. M., D. E. Noakes, A. Rycroft, and H. Dobson. 2001. Acute phase protein response to postpartum uterine bacterial contamination in cattle. Vet. Rec. 148:172-175.

Sheldon, I. M., D. E. Noakes, A. N. Rycroft, D. U. Pfeiffer, and H. Dobson. 2002. Influence of uterine bacterial contamination after parturition on ovarian dominant follicle selection and follicle growth and function in cattle. Reproduction 123:837-845.

Sheldon, I. M., E. J. Williams, A. N. A. Miller, D. M. Nash, and S. Herath. 2008. Uterine diseases in cattle after parturition. Vet. J. 176:115-121.

Shrestha, H. K., T. Nakao, T. Suzuki, T. Higaki, and M. Akita. 2004 Effects of abnormal ovarian cycles during pre-service period postpartum on subsequent reproductive performance of high-producing Holstein cows. Theriogenology 61:1559-1571.

Sordillo, L. M., and S. L. Aitken. 2009. Impact of oxidative stress on the health and immune function of dairy cattle. Vet. Immunol. Immunopathol. 128:104-109.

Spears, J. W., and W. P. Weiss. 2008. Role of antioxidants and trace elements in health and immunity of transition dairy cows. Vet. J. $176: 70-76$.

Spicer, L. J., W. B. Tucker, and G. D. Adams. 1990. Insulin-like growth factors in dairy cows: Relationships among energy balance, body condition, ovarian activity, and estrous behavior. J. Dairy Sci. 73:929-937.

Sprecher, D. J., D. E. Hostetler, and J. B. Kaneene. 1997. A lameness scoring system that uses posture and gait to predict dairy cattle reproductive performance. Theriogenology 47:1179-1187.

Staples, C. R., W. W. Thatcher, and J. H. Clark. 1990. Relationship between ovarian activity and energy balance during the early postpartum period of high producing dairy cows. J. Dairy Sci 73:938-947.

Stojević, Z., J. Piršljin, S. Milinković-Tur, M. Zdelar-Tuk, and B. B. Ljubić. 2005. Activities of AST, ALT and GGT in clinically healthy dairy cows during lactation and in the dry period. Veterinarski Arhiv 75:67-73.

Taylor, V. J., Z. Cheng, P. G. Pushpakumara, D. E. Beever, and D. C. Wathes. 2004. Relationships between the plasma concentrations of insulin-like growth factor-I in dairy cows and their fertility and milk yield. Vet. Rec. 155:583-588.

Thatcher, W. W., T. R. Bilby, J. A. Bartolome, F. Silvestre, C. R. Staples, and J. E. P. Santos. 2006. Strategies for improving fertility in the modern dairy cow. Theriogenology 65:30-44. 
Thatcher, W. W., and C. J. Wilcox. 1973. Postpartum estrus as an indicator of reproductive status in the dairy cow. J. Dairy Sci. 56:608-610.

Trimberger, G. W. 1948. Breeding efficiency in dairy cattle from artificial insemination at various intervals before and after ovulation. Nebraska Agric. Exp. Stn. Res. Bull. 153:1-26.

Trimberger, G. W., and H. P. Davis. 1943. Conception rate in dairy cattle from artificial insemination at various stages of estrus. Nebraska Agric. Exp. Stn. Res. Bull. 129:1-14.

Turner, R. J., and J. M. Finch. 1991. Selenium and the immune response. Proc. Nutr. Soc. 50:275-285.

Vicini, J. L., F. C. Buonomo, J. J. Veenhuizen, M. A. Miller, D. R. Clemmons, and R. J. Collier. 1991. Nutrient balance and stage of lactation affect responses of insulin, insulin-like growth factors I and II, and insulin-like growth factor-binding protein 2 to somatotropin administration in dairy cows. J. Nutr. 121:1656-1664.

Villa-Godoy, A., T. L. Hughes, R. S. Emery, L. T. Chapin, and R. L. Fogwell. 1988. Association between energy balance and luteal function in lactating dairy cows. J. Dairy Sci. 71:1063-1072.

Walsh, R. B., D. F. Kelton, T. F. Duffield, K. E. Leslie, J. S. Walton, and S. J. LeBlanc. 2007. Prevalence and risk factors for postpartum anovulatory condition in dairy cows. J. Dairy Sci. 90:315-324.

Wathes, D. C. 2012. Mechanisms linking metabolic status and disease with reproductive outcome in the dairy cow. Reprod. Domest. Anim. 47(Suppl. 4):304-312.

Wathes, D. C., Z. Cheng, M. A. Fenwick, R. Fitzpatrick, and J. Patton. 2011. Influence of energy balance on the somatotrophic axis and matrix metalloproteinase expression in the endometrium of the postpartum dairy cow. Reproduction 141:269-281.

Wathes, D. C., M. Fenwick, Z. Cheng, N. Bourne, S. Llewellyn, D. G. Morris, D. Kenny, J. Murphy, and R. Fitzpatrick. 2007. Influence of negative energy balance on cyclicity and fertility in the high producing dairy cow. Theriogenology 68(Suppl. 1):S232-S241.

Williams, E. J., D. P. Fischer, D. E. Noakes, G. C. England, A. Rycroft, H. Dobson, and I. M. Sheldon. 2007. The relationship between uterine pathogen growth density and ovarian function in the postpartum dairy cow. Theriogenology 68:549-559.

Williams, E. J., D. P. Fischer, D. U. Pfeiffer, G. C. W. England, D. E. Noakes, H. Dobson, and I. M. Sheldon. 2005. Clinical evaluation of postpartum vaginal mucus reflects uterine bacterial infection and the immune response in cattle. Theriogenology 63:102-117.

Williams, E. J., K. Sibley, A. N. Miller, E. A. Lane, J. Fishwick, D. M. Nash, S. Herath, G. C. W. England, H. Dobson, and I. M. Sheldon. 2008. The effect of Escherichia coli lipopolysaccharide and tumour necrosis factor alpha on ovarian function. Am. J. Reprod. Immunol. 60:462-473.

Zollner, U., K. Lanig, T. Steck, and J. Dietl. 2001. Assessment of endocrine status in patients undergoing in vitro fertilization treatment. Is it necessary? Arch. Gynecol. Obstet. 265:16-20. 